\title{
ロ蓋に発生した筋上皮腫の1 例
}

\author{
岡田宗久·重松久夫・志田裕子 \\ 鈴木正二·草間＼cjkstart薰* 坂下英明
}

\section{A case of myoepithelioma in the palate}

\author{
OKADA Munehisa · SHIGEMATSU Hisao $\cdot$ SHIDA Hiroko \\ SUZUKI Seiji · KUSAMA Kaoru * · SAKASHITA Hideaki
}

\begin{abstract}
A 50-year-old man was referred to our hospital because of a growth in the right side of the hard plate. Radiographic and computed tomographic examinations showed a unilocular radiolucent lesion with a well-circumscribed margin, involving a palatal root of the first molar. Magnetic resonance imaging (T2-weighted) showed increased signal intensity of the tumor. A possible diagnosis of pleomorphic adenoma was made on biopsy, and partial maxillectomy was performed. There has been no evidence of recurrence as of 1 year 8 months after the operation.

Histopathologically, the tumor was well encapsulated by fibrous tissue and consisted of elliptical or rounded cells, with homogenous eosinophlic cytoplasm and eccentrically placed nuclei. The pathological diagnosis was myoepithelioma. Immunohistochemically, S-100 protein, vimentin, glial fibrillary acidic protein (GFAP), actin, and wide keratin were positive. Immunoreactivity for $35 \beta \mathrm{H} 11$ or $34 \beta$ E12 was not detected clearly or markedly. Cells positive for PCNA, MIB-1, or both were rare.
\end{abstract}

Key words: salivary gland tumor (唾液腺腫瘍), myoepithelioma（筋上皮腫）, plasmacytoid cell（形質細胞様細胞）, immunohistochemistry (免疫組織化学), palatal gland (口蓋腺)

\section{緒言}

筋上皮腫は 1991 年にWHO 唾液腺腫瘍分類の改定で多 形性腺腫から独立して取り扱われるようになった ${ }^{1)}$. 発生 頻度は唾液腺腫瘍の $1 \sim 1.5 \%$ 以下と比較的まれで，口蓋 や耳下腺部の無痛性腫瘤として認められる ${ }^{1 \sim 3)}$. 今回わ れわれは，口蓋に発生した筋上皮腫を経験したので免疫組 織化学的検討を加えて報告する.

症例
患 者：50 歳, 男性.
初 診: 2001 年 6 月
主 訴：右側口蓋部の腫瘤.

明海大学茵学部口腔外科学第 2 講座

(主任：坂下英明教授)

* 明海大学蒌学部口腔病理学講座

(主任：草間 薰教授)

Second Department of Oral and Maxillofacial Surgery, Meikai University School of Dentistry (Chief: Prof. SAKASHITA Hideaki)

* Department of Oral Pathology, Meikai University School of Dentistry (Chief: Prof. KUSAMA Kaoru)

受付日：2003 年 8 月 14 日

採択日：2003 年11月 18 日
既往歴・家族歴：特記事項なし.

現病歴：2001年 4 月，右側口蓋の腫瘤ならびに接触痛 に気づくも放置していた，6月，風邪のため近医を受診し た際に, 腫瘤の精査を勧められ紹介にて来院した。

全身所見：体格中等度, 栄養状態良好.

口腔内所見： 6 部を中心に硬口蓋に $40 \times 22 \mathrm{~mm}$ の腫瘤 を認め, 偽波動を触知した。自発痛や圧痛は認めなかった (写真 1 ).

画像所見：CT および MRI 写真で，病変は周囲骨を圧迫 吸収するとともに上顎洞底を押し上げ，一部で骨欠損が疑 われた $($ 写真 $\mathbf{2} \mathbf{a}, \mathbf{b})$. また, MRI 写真において, 病変内部 は T1 強調像で低信号, T2 強調像で高信号, 造影 MRI 写真 では内部不均質な像を呈していた。

\section{臨床診断：口蓋部良性腫瘍.}

処置および経過：2001年 8 月 試験切除を施行し多 形性腺腫と診断した。生検時の所見では，粘膜下に充実性 で死白色の腫瘍を認めたが, 腫瘍は弾性軟で被膜も薄く, 摂子でつまむと容易に崩れる脆弱な腫瘤であった。このこ とから, 腫瘍周囲の被膜はきわめて不十分なものと考え, また，柬槽突起部も広範囲に圧迫吸収を受けていることか ら, 病変の切除にあたっては上顎骨部分切除術が必要と考 
えた８月ロ， $5 \mathrm{~mm}$ の安全域をとり，5 部一上靧絬節 にかけて上䫈骨部分切除術を施行した。すなおち，腫瘍周 囲の健常な骨に骨バーを用い上須洞と鼻腔の粘膜を明ホで きるまで淦を形成し, 慎重に粘膜を剥離した。この際, 腫 陽の鼻腔側に一層の菲溥な骨の介在を認めたことから，鼻 腔および上䫈洞粘膜は温存叮能と判断した。術中，粘膜は 完全に保存し得たが，術後に鼻腔粘膜に穿孔が生じ，徐々 に搪大してロ腔鼻腔瘦を形成した。腔鼻腔㾞については, 2002 年 4 月，健側の口蓋弃老用い閉鎖した。上顛骨 部分切除術後 2 年 1 か月経過し, 再発の所見はない.

病理組織所見：腫瘍は線維性組織で被包され，腫瘍紐胞

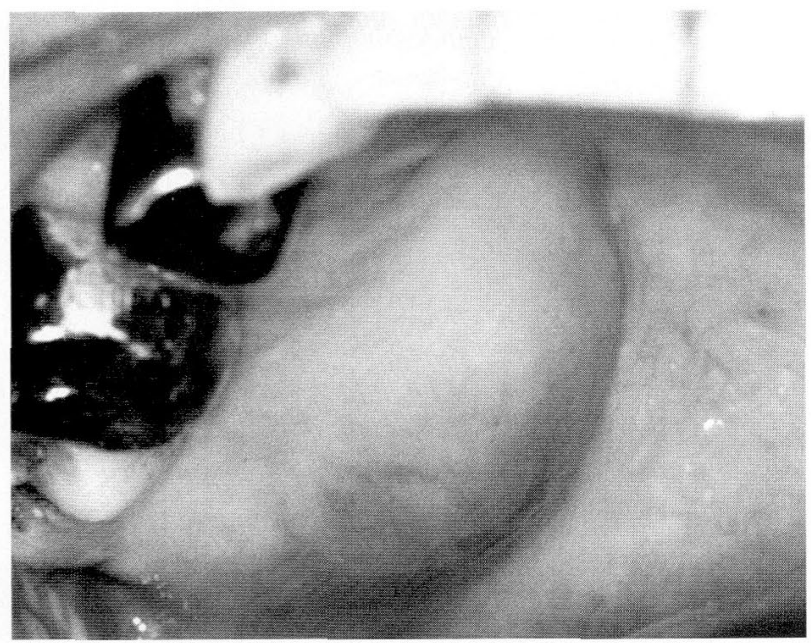

写真 1 初診時口腔内写真 弾性軟の無痛性腫脹を呈していた。
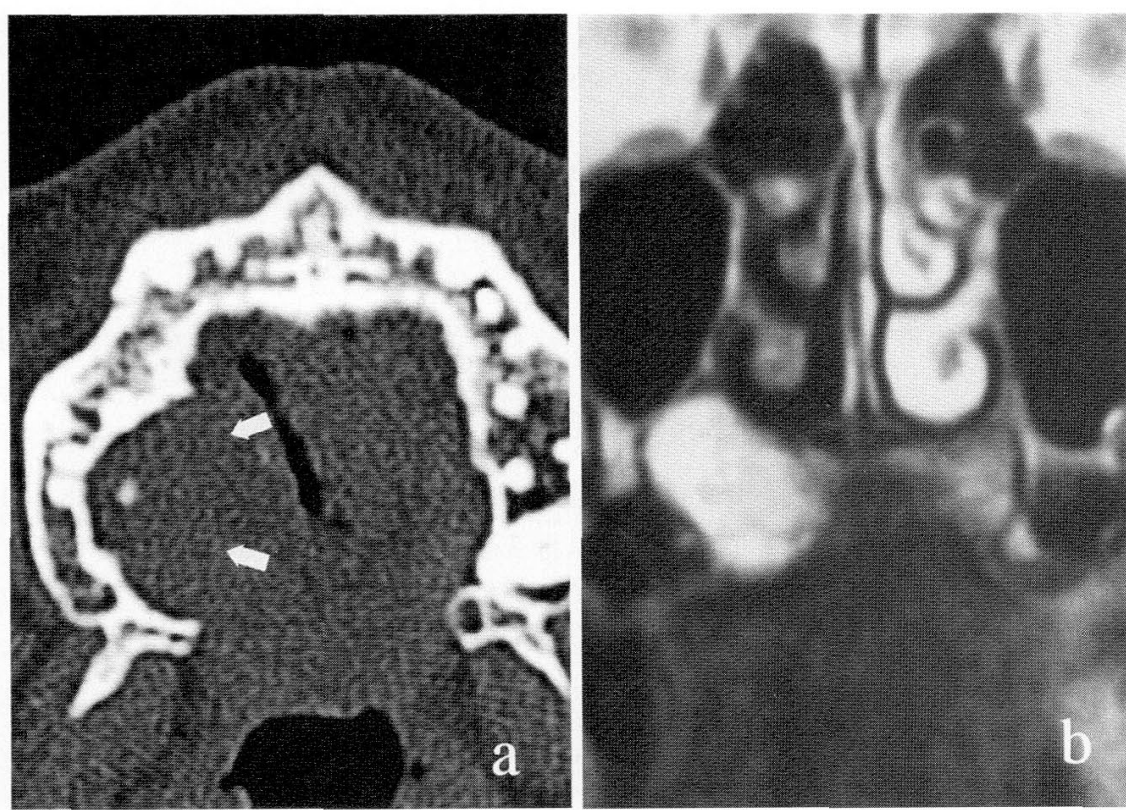

写真 2 初診時 CT ならびに MRI 像

病変は CT 写真で周囲骨を圧迫吸収するとともに (a), MRI-T2 強調像で高信 号を呈していた（b).
の被膜内浸潤はみられなかった。腫瘍細胞は均質な好酸性 胞体と偏在する核を有し，類门形ないし多角形を呈する形 質細胞様細胞であり，硝子様結合組織の混在を認めた。形 質絊胞様細胞が大小の充实性胞栄孝形成し，胞巣内には明 らかな腺房や導管の形成所見は認妨なかた（写真 $3 a, b)$. また、ごく一部に紡錘形細胞の混在する部分も認められた.

免疫組織化学的検索では腫瘍性筋上皮細胞のマーカーで ある S-100 蛋ウや vimentin, glial fibrillary acidic protein (GFAP)，actinに対して明らかな陽性所見が認められた (写真 $4 \mathrm{a} \sim \mathrm{e})$. 一方, cytokeratin については広範囲 keratin (keratin wide) で陽性を示したが，35 月 H11 は陰性， 34 ア E12 もほとんど陽性細胞を認めなかった。腫瘍細胞の 增殖能を評価するためPCNA と MIB-1に対する各抗体を 用いて検索したが，いずれも陽性細胞は散在性に認められ るに過ぎなかった（表 1 ).

病理組織診断：形質細胞様練胞型筋上皮腫。

\section{考察}

筋上皮腫の名称は 1943 年 Sheldon ${ }^{4 ｝ \text { が so-called mixed }$ tumorの分類のなかで筋上皮由来の腫瘍細胞のみからなる ものに対して使用したのが初めである。腫瘍性筋上皮細胞 には plasmacytoid cell と spindle cellの 2 種類が当初より 知ら扎て打り，こ扎らの細胞のみからなる唾液腺腫瘍が本 名称で報告されたが，いずれも多形性腺腫の一曲型とみな されていた ${ }^{4-6)}$. 1991 年，本腫瘍は多形吽腺腫と比較して 浸潤性や悪性転化の傾向が強いとして独立した疾患に分類 され，さらに，その構成細胞の特徵か ら紡鍾形紏胞型，形質細胞様細胞型， 上皮様細胞型，明細胞型打よびこれら の混合型に曲分類された ${ }^{1,7}$.

本腫瘍の構成細胞が光顕的に多彩 な所見を示すことから，腫痬性筋上皮 細胞としての証明が免疫組織化学的 になされてきて打り ${ }^{9)}$ ，S-100 蛋白や vimentinの存在が筋上皮細胞由来の 根拠とされている ${ }^{6,9)}$ 。また，腫瘍性 筋上皮における actin や myosin の染 色性は必ずしも一定ではないが9，こ れら收縮蛋白の証明は筋上皮細胞の 同定上，強い証拠といえる。GFAPの 正常筋上皮に打ける局在については 否定的な報告 ${ }^{9)}$ があるが，紡錘形細 胞型を除く腫瘍性筋上皮細胞では陽 性を示すとの報告 ${ }^{3)} も$ あ。すなわ ち，腫瘍性筋上皮細胞は正常筋上皮細 胞の特徵をす心゙て備えているとは限 
らず，また，正常唾液腺では認められない形質の発現を伴

うこともある。自験例では腫瘍性筋上皮細胞のマーカーと して S-100蛋白, vimentin, GFAP，および actin を対象とし て検討した結果，これらす心゙てに対して明らかな陽性所見
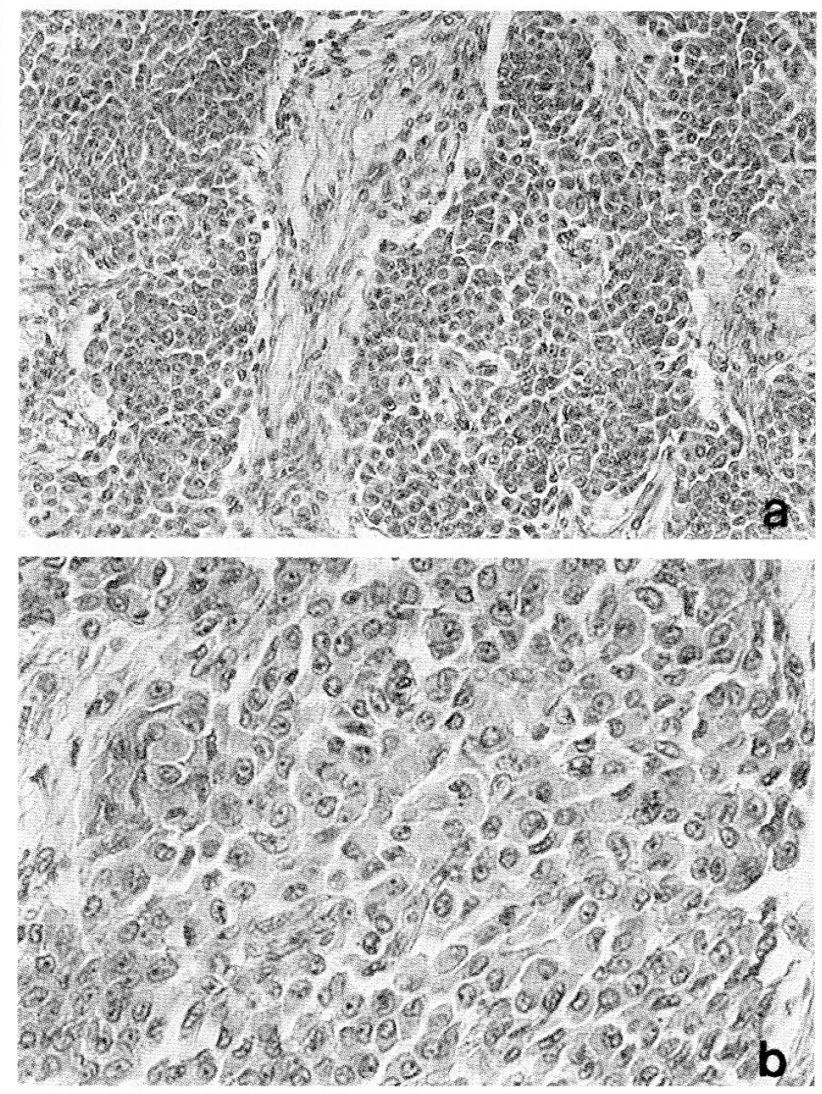

写真 3 切除標本の病理組織像

HE 染色標本で腫場細胞は類円形ないし多角形を是する 形質細胞様細胞から構成されていた（a: 低倍率, b: 高倍率).
が確認され，形質細胞様細胞型筋上皮腫に関するこれまで の報告 ${ }^{6}$ ８, 10) とほぼ一致していた。

本腫瘍は，一方的に篎上皮性分化を示すとは限らず，導 管上皮方向への分化索伴うことも推測されている ${ }^{9,11)}$. 構 成成分のなかで僅かながら導管構造が認められる場合には myoepithelial cell adenoma として区別すべきとの考え方も あるが ${ }^{8)}$ ，純粋な筋上皮腫はむしろまれともいわれる7). さらに坆下ら ${ }^{12)}$ は多形性腺腫の需型分類に際して，管上 皮成分が優性で筋上皮腫に類似しているものを筋上皮腫類 似型と分類している。上皮性分化について自験例では抗 cytokeratin 抗体として keratin wide, $34 \beta \mathrm{E} 12,35$ \% H11 用いて検討した. Keratin wide は cytokeratin 1，5，6，8， 13，16 に陽性を示し，筋上皮にも反応する．34 $\beta$ E12 は cytokeratin 1, 5, 10,14に陽性を示し，正常細胞では扁平上

表 1 免疫組織化学的評価（使用抗体）

\begin{tabular}{c|c|c|r}
\hline 抗体 & 特異 性 & (製造元) & $\begin{array}{l}\text { 抗 体 の } \\
\text { 希釈倍率 }\end{array}$ \\
\hline S-100 protein & S-100 protein & DAKO & 2000 倍 \\
\hline V-9 & vimentin & DAKO & 200 倍 \\
\hline GFAP & GFAP & DAKO & 400 倍 \\
\hline 1 A4 & muscle actin & IMMUNON & 15 倍 \\
\hline Keratin wide & CK 1, 5, 6, 8, 13,16 & DAKO & 2000 倍 \\
\hline $34 \beta$ E12 & CK 1, 5, 10,14 & IMMUNON & 30 倍 \\
\hline $35 \beta$ H11 & CK 8 & IMMUNON & 5 倍 \\
\hline PC10 & PCNA & Novocastra & 15 倍 \\
\hline MIB-1 & MIB-1 & DAKO & 25 倍 \\
\hline
\end{tabular}
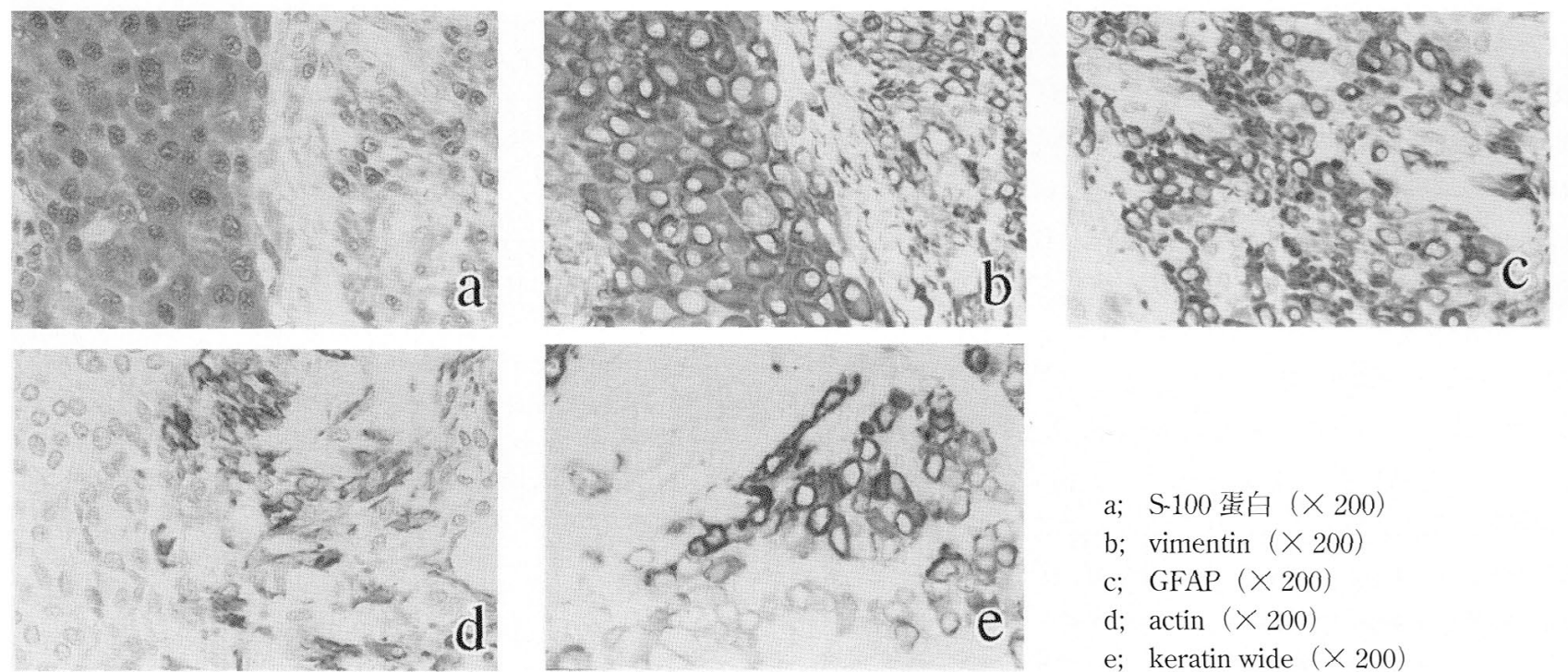
a; S-100 蚠白 $(\times 200)$
b; vimentin $(\times 200)$
c; $\operatorname{GFAP}(\times 200)$
d; $\operatorname{actin}(\times 200)$
e; keratin wide $(\times 200)$

写真 4 免疫組織染色像

免疫組織化学的染色で, 腫瘍紼胞は各抗体に対して明らかな陽性所見を呈していた $(\times 200)$. 
皮，腺上皮などと，腫瘍細胞では腫痬化した扁平上皮，導 管上皮，円柱上皮と反応する。一方，35 $\beta$ H11 は cytokeratin 8 に特異的に反応し, 腺癌の検索に有用とされる。これ らの抗体を用いた免疫組織化学的検討の結果，自験例では keratin wide は陽性, $35 \beta \mathrm{H} 11$ は陰性, $34 \beta \mathrm{E} 12$ に対しては ほとんど陽性細胞を認めなかった，結論として，自験例で は導管上皮と筋上皮の 2 方向の分化能力をもつ腫瘍性細胞 が，もっぱら筋上皮へ分化したものと推察された。

本腫瘍は多形性腺腫に比較して増殖能が高いとの報告 ${ }^{1)}$ があることから，その増殖能について多くの比較検討がな されてきた。しかしながら，PCNAを用いた検討では必ず しも一致した見解が得られているわけではなく ${ }^{13)}$, 多形性 腺腫と筋上皮腫のどちらの細胞活性が高いか現時点では断 定しかねる。また，形質細胞様細胞については，電顕的観 察所見にて，細胞内には中間大フィラメントが充満してお り，変性過程にある細胞との見方もある ${ }^{5,14)}$. 自験例では 細胞活性を評価するために PCNA と MIB-1 を用いて検討 したが，結果として陽性細胞は散在性に認められるに過ぎ ず，高い増殖能を示唆する所見は得られなかった。

本腫瘍の発生部位は諸外国では耳下腺が 40 ～ $48 \%$ と多 いが 2,11$)$, 本邦では口蓋腺が $50 \%$, 耳下腺が $17 \%$ と口蓋 での報告が多い ${ }^{3)}$. 発生は全年齢にみられるが，特に中年 以降に多く3,11)，一般に無痛性で弾性硬の腫瘤として触知 される ${ }^{2,3,10)}$ 。自験例は中年で口蓋部の無痛性腫瘤である 点は一致していたが，硬さは弾性軟であった。鑑別すべき 疾患としては口蓋の多形性腺腫をはじめとした良・悪性の 唾液腺腫瘍 $2,7,15)$ ，㐘原性腫瘍や非柬原性腫瘍，その他自 験例のように軟かな病変として触知される場合には囊胞や 蒾性感染症なども鑑別すべき疾患としてあげられる，画像 診断は病変の広がりを知る上で有効であり，増大にともな い骨の圧迫吸収像を呈する．MRI 所見は境界明瞭，T1強 調で低信号，T2 強調で高信号，また造影 MRIでは腫瘍内 部の状態により均一もしくは不均一な像を呈するなど, 多 形性腺腫の所見と類似する. 自験例では病变が根尖を含み, 弾性軟で偽波動を触知したことから柬性疾患との鑑別も考 慮して術前に生検を施行し手術法を決定した。

本腫瘍の治療法については多形性腺腫と同様に被膜内浸 潤に留意した外科的切除を基本とするが $2,3,7,8)$ ，浸潤性増 殖, 被膜の袁失, 明らかな細胞異型が認められれば臨床的には 癌腫として拡大切除が適応となる ${ }^{11,14)}$. 自験例では，生検時 の所見で腫瘍が非常に脆い病変であったこと，画像所見で 病変が㐘槽へ広がり歯根を取り込んでいたこと, 硬口蓋部 の骨の著明な吸収を認めたことなどから，腫痬を一塊とし て切除するために上顎骨部分切除術を選択した。本腫瘍は 再発や悪性転化に関する報告 $1,2,10,16)$ が散見されることか ら, 今後とも注意深い経過観察が必要であると考えている.
結

語

本論文では口蓋の筋上皮腫（形質細胞様細胞型）の 1 例 を経験したのでその概要を報告した，筋上皮腫に関する病 理組織学的・免疫組織化学的検討については，再発や悪性 転化などの臨床病態に関する評価とともに，今後さらに症 例を蓄積して検討する必要がある。

\section{引用 文 献}

1) Seifert, G., Sobin, L.H., et al.: Histological Typing of Salivary Gland Tumor. 2nd Ed, Berlin, SpringerVerlag, 1991, p12.

2) Ellis, G.L. and Aculair, P.L.: Myoepithlial carcinoma. Tumor of the salivary glands: In Atlas of tumor pathology. 3rd series, AFIP, Washington D.C., 1996, p57-68.

3）佐藤美知子, 吉原俊雄：耳下腺筋上皮腫の 2 例と文 献的考察. 耳鼻臨床 47: 5-10 2001.

4) Sheldon, W.H.: So-called mixed tumors of the salivary glands. Arch Pathol 35: 1-20 1943.

5）榎本武司，堀 稔，他：軟口蓋に生じたいわゆる 筋上皮腫の 1 例. 日口外誌 31: 351-356 1985.

6) Dardick, I., Cavell, S., et al.: Salaivary gland myoepithelioma variants. Histological, ultrastructural, and immunocytological features. Virchows Archiv [A] 416: 25-42 1989 .

7）岡部孝一，宮田 勝，他：口蓋に発生した筋上皮腫 の 1 例. 口科誌 50: 310-314 2001.

8）川辺良一，増田元三郎，他：小唾液腺の plasmacytoid myoepithelioma 一軟口蓋に生じた 1 症例とそ の文献的考察一。日外誌 37: 1055-1062 1991.

9）二階宏昌，小川郁子，他：唾液腺腫瘍の免疫組織化 学一腫瘍性筋上皮の染色所見を中心に一。病理臨床 7: 574-581 1989.

10）伊藤良明，石川武憲，他：口腔小唾液腺の悪性筋上 皮腫の 2 例 悪性転化の推定された例. 日口外誌 47: 170-173 2001.

11) Cowson, R.A., Binnie, W.H., et al.: Lucas's pathology of tumors of oral tissue. $5^{\text {th }}$ Ed, ChurichillLivingstone, Edinburgh, 1998, p373.

12）坂下英明, 宮田 勝, 他：唾液腺腫瘍の病理組織学 的研究. 特に多形性腺腫の亜分類と被膜との関係に ついて. 日外誌 35: 2638-2646 1989.

13) Yang, L., Hashimura, K., et al.: Immunoreactivity of proliferating cell nuclear antigen in salivary gland tumors: an assessment of growth potential. Virch A Pathol Anat Histo 422:481-486 1993.

14) Kusama, K., Sanuki, N., et al.: Hyaline cell in minor salivary gland tumors - Morphological, immunohistochemical and electron microscopic study -. Jpn J Oral Biol 25: 596-599 1983.

15）朔 敬, 周 志瑜：唾液腺筋上皮腫. 病理と臨床 17: 824-825 1999.

16) El-Naggar, A., Batsakis, J.G., et al.: DNA content and proliferative activity of myoepitheliomas. J Laryngol Otol 103: 1192-1197 1989. 